\title{
Afrikaner spirituality: \\ A complex mixture
}

\author{
Erna Oliver \\ Department of Christian Spirituality \\ Church History and Missiology \\ University of South Africa
}

\begin{abstract}
The article argues that the perception that Afrikaner spirituality is and has always been founded mainly or only upon the Calvinistic tradition is a misconception. Nineteenth century Afrikaner spiritualism consisted of a mixture of theology, philosophy and a way of adapting to extreme living conditions. These factors, although with different contents, are also the determinant issues that made $21^{\text {st }}$ century Afrikaner spirituality such a complex phenomenon. The article postulates that the Afrikaner nation's current identity crisis can be resolved by closely looking at the different influences on the spirituality of the nation and by carefully guiding the people through the complex set of multiple choices to a fresh relation with Christ in a new found Christian identity to confirm our Christian foundation.
\end{abstract}

\section{INTRODUCTION}

In a recent article in the Nederduitse Gereformeerde Teologiese Tydskrif Steyn (2005:550) states that the Nederduitse Gereformeerde Kerk (Dutch Reformed Church) finds itself in an identity crisis. This crisis centres on the "Reformed identity" of the church. Steyn (2005:550) proves this by referring to the huge number of recent publications regarding this matter. The Reformed identity forms part of the bigger issue, which is the more complex topic of Afrikaner spirituality. Spirituality can be seen as the total religious personality and perspective of people, influencing their total being: their worldview, acts, speech, thinking and emotions. It seems as if the traditional sacred method of writing and working with South African (church) history (Den Boer 1966:33) and the so-called "Reformed identity" of the Afrikaner nation resulted in the perception that Afrikaner spirituality is and always has been founded mainly (or only) upon the Calvinistic tradition. This perception is contributing to the crisis. 


\section{Afrikaner spirituality: A complex mixture}

Saayman (2005) compares the situation in the Dutch Reformed Church (and we can include the other Afrikaans speaking churches in this comparison) to a dam, which for more than 300 years took water from many different streams, rivers and brooks, absorbing all the water into one giant collective pool. These rivers and streams of variable strengths and volumes are Christianity, the Reformation, the Second Reformation, Pietism, Methodism, Liberalism, Calvinism and the Charismatic movement, to name only the most important theological influences. When all of these, as well as the non-theological influences on Afrikaner spirituality, are taken into account, it becomes clear that it is incorrect to assume that Calvinism forms the only or even the most important part of Afrikaner spirituality. Froise (2004:7) argues in her thesis that the Afrikaans speaking churches use Calvinism as a convenient label and hiding place in the current storm. Should this statement be true, the church needs to urgently rethink its identity.

An historical critical investigation of primary and secondary sources shows that some of the concepts that are nowadays held as the major portion of the heritage of Afrikaner religion and spirituality are indeed a later interpretation by both historians and church historians, while the fact that Afrikaner spirituality is a complex mixture of various sources is usually overlooked. The fact that the religion of the Afrikaner nation for nearly 300 years was based mainly on the Old Testament Scriptures is also overlooked. Although Calvinism had a huge influence on Afrikaners in the latter part of the $19^{\text {th }}$ century (from approximately 1870) and the first half of the $20^{\text {th }}$ century, other traditions and influences also contributed significantly to Afrikaner spirituality and became mixed with Calvinistic trends.

A brief overview of modern-day Afrikaner spirituality reveals a complex mixture of theology, philosophical influences and unique living conditions. The similarities between the $19^{\text {th }}$ century Afrikaner spirituality and that of the $21^{\text {st }}$ century are too obvious to be ignored. The recognition of the similarities can help to speed up the process of providing guidelines and possible answers as well as identifying possible cornerstones on which a new identity can be built.

\section{THE COMPLEX AFRIKANER SPIRITUALITY OF THE $19^{\text {th }}$ CENTURY}

The moment the European settlers set foot on African soil, a new nation was formed. A variety of influences and circumstances made its mark on the Afrikaners. Although most of these influences can be named individually, their impact on society cannot be separated from one another. First and foremost was the firm dependence on religion. Other factors were education, politics, and the land (the climate, living conditions and the wilderness surrounding 
them), as well as ethnological, economical, social, cultural and historical influences (cf Nepgen 1938:47-49). The population developed a unique individuality, a distinctive character that can be summarised with the words of Moodie: "The manners and habits of the Dutch have an extraordinary similarity from one extremity of the colony to the other. They seem indeed to be all fashioned after one model; and few individual peculiarities are to be found in one character that may not be possessed in a greater or smaller degree in another" (Moodie 1835:146, 147).

Akenson $(1992: 59,60)$ divides the pre-1948 years of Afrikaner history into four periods: the Dutch colonial era before 1806, including the first British occupation of 1795-1802; the period between the long-term occupation of the Cape by the United Kingdom in 1806 and 1870, when the Afrikaner identity began to crystallize; 1870-1910, a period of rapid cultural development; and 1910-1948, when the Afrikaner identity began to assume the character of an endoskeleton strong enough to determine and to control the apparatus of a modern state. The second of these periods provides us with a slightly wider glimpse of the different influences on Afrikaner spirituality. These influences are divided into two main categories namely the different religion related traditions on the one hand and influences like the unique living conditions and the general worldview of the Afrikaners on the other hand.

\subsection{Religion related influences on Afrikaner spirituality}

\subsubsection{Religion}

Giliomee (1975:3) states that the Cape settlers regarded and described themselves as Christians and he quotes MacCrone (1961):

In the seventeenth century men were in the first place Catholics or Protestants, Christians or non-Christians." Modern-day scholars agree with primary sources that religion played a very important part in the lives of the Afrikaners, and that they cannot be understood if one does not take into account their religion, because their total existence evolved around it.

(Nepgen 1938:58)

Rose, an Englishman, residing in South Africa for twelve years, wrote The truth about the Transvaal in 1902. He claims that religiosity is the main characteristic of the Afrikaners, colouring every aspect of their lives (Rose 1902:10, 11, 17, 19). 
Jeppe, who came to South Africa as a young man and lived in Pretoria, quickly summed up the typical Afrikaner. It seems as if his youth gave him the open-mindedness to understand the Afrikaner better than other people coming from abroad. He writes: "The religious sentiment in the Boer has been often scoffed at; it certainly sometimes verges on cant, and naturally it is not equally sincere in all individuals; but upon the whole it is unfeigned and deepseated" (Jeppe 1906:75).

Fifty years earlier, in 1854, Stuart (who was an immigrant trying to sell farms in the ZAR to the people in the Netherlands and used his book De Hollandshe Afrikaneren en hunne republiek in Zuid-Africa as advertisement to do so) remarks on the public display of religion in the ZAR:

The first building when a town is founded is the Church. All the people work together, every one brings whatever he can to help and they work without stopping, like bees in a cove. The Churches are big, simple, and used only for religious purposes. Everybody respects the members of the Church council and they have great influence in the community.

(Stuart 1854:213 - verbatim)

Lichtenstein, who came to the Cape with governor Jansens in 1803-1806 (Hoge 1945:172) notes that he "... never heard from the mouth of a colonist an unseemly word, an overstrained expression, a curse, or an imprecation of any kind .... The universal religious turn of the colonists, amounting almost to bigotry, is perhaps, a principal cause to which this command of themselves is to be ascribed" (Lichtenstein 1928:116). Van der Merwe (1995:199) quotes other travellers who said the same thing about Afrikaner religion in the 1830's. One of the main reasons could be that the Christian foundation was given to the children on the knees of their mothers. By the time they were grown-ups, religion was part of their character and worldview (cf Stockenström sa:229).

Wichmann (1941:3) is correct by noting that the Bible was the focal point of Afrikaner religion. Fuller comments on this: "The reading of the Sacred Book was all in all to them. Their forefathers in Holland and France had suffered for freedom to read its life-giving pages, and they with inherent steadfastness sought therein the bread of life" (Fuller 1908:164). Although it is true that Afrikaner spirituality in the $19^{\text {th }}$ century was founded on religion, and that the source of this religion was the Bible, the claim that the Afrikaner nation was Christians (in a modern-day sense of the word) seems to be a misconception. Of course they were Protestants with the strong heritage of the Reformed tradition in the form of the Synod of Dordt influencing and 
shaping their lives (Oliver 2005:92, 93), but it was in the pages of the Old Testament that the Afrikaners found God. "The Old Testament stands Bible to the Afrikaner; this nation has been described as the modern counterpart of an Old Testament tribe" (Calpin 1944:17). On this, Fuller comments: "In character, he is different from all others: he maintains a kind of patriarchal religion" (Fuller 1908:36). A few years earlier, Rose $(1902: 10,11)$ also stated:

\begin{abstract}
Based far more upon the Old than the New Testament, it [the religion of the Afrikaner] is simply part and parcel of his daily life, and, personally, I could far more easily imagine a Boer dispensing with his breakfast than with his morning prayers, or with his supper than with his evening psalm singing. He is, so to say, unconsciously religious; it simply never enters into his head to be otherwise.
\end{abstract}

Akenson studied the parallels between ancient Israel and the Afrikaners and came to the conclusion that the Afrikaner way of reading the Bible and the theology that emerged among the Afrikaner clergy and laity, was Christian only in theory. "Afrikaners used the Old Testament almost exclusively; Christology was almost nonexistent" (Akenson 1992:61). He also notes that " ... the Afrikaners possessed a folklore, for the most part of historical memories handed down within families. The Afrikaners thought historically, not in the same way that historians might, but they used history as the ancient Hebrews did, to explain the past in moral terms and to guide their planning for the future" (Akenson 1992:63).

Both primary and secondary sources agree that although the world of the Afrikaner nation in the $19^{\text {th }}$ century revolved around religion, it was practiced in a unique way with emphasis on the Old Testament rather than the New Testament.

\title{
2.1.2 Pietism, methodism and liberal theology
}

Pietism is a German Lutheran reform movement of the $17^{\text {th }}$ and $18^{\text {th }}$ centuries that emphasised individual conversion, "living faith" and the fruits of faith in daily life (Pretorius 1988:165). Pietists held prayer meetings, studied the Bible individually and in small groups, and led a disciplined Christian life (Deist 1984:130). Convinced that the world could be won for Christ through the conversion and Christian training of individuals, Pietism also stressed the importance of education. Related to Pietism, Deist sees Methodism as " $(t)$ he church dogma and ecclesiastical practice of John Wesley and his followers, strongly emphasizing personal conversion, religious experience, Bible study, and private and public prayer" (Deist 1984:104). 
After their initial success, religious movements tend to transform into dogma. Although this also started to happen to Calvinism in the Netherlands by the beginning of the $17^{\text {th }}$ century, the religion stayed a living stream of water due to the works of Pietist theologians who firmly believed that faith living in the hearts and minds of the people must be practised in everyday life. Through the works of Lodensteijn, à Brakel and Smytegelt (all of whom had great influence on the Afrikaners - Engelbrecht 1977:58), faith became a living lifestyle, determining the worldview and character of the Afrikaner nation. The enormous influence that the seventeenth century Dutch Pietist writers of the Second Reformation had on the forming of the spirituality of the Afrikaner nation cannot be over emphasised. Raath (2004:139) states: "However it can categorically be stated that à Brakel's work was the most widely read theological work among the Dutch Boers on the Cape frontier and in the interior of the country before the establishment of the Boer Republics and shortly thereafter." Raath (2004:134) also notes that à Brakel"s influence was not limited to church issues only. Landman (2005:148) emphasises the enormous influence of à Brakel on the total spectrum of the $19^{\text {th }}$ century world of the Afrikaners by saying that "the restrictive and submissive piety inherited by Afrikaner women from $17^{\text {th }}$ century Dutch pietism" has not changed in 300 years.

The German traveller, W von Meyer, observed a "trend towards Pietism" among the Afrikaners (Von Meyer 1843:171). A strong influence of Pietism, especially in the song education and expression of "living faith" cannot be denied (cf Oliver 2005:116, 117). On his journey through the ZAR in 1853 , Rev Neetling was delighted to find a "living faith" on the farms. People were living like the patriarchs of the Old Testament (Stuart 1854:408) and the Bible knowledge of the youth, living in the isolated town of Lydenburg, was much better than that of the young people living in the Cape Colony (Stuart 1854:380).

Some scholars, like Van der Walt and Schonken, believe that the only religious influence on the Voortrekkers came from the Reformation partly because of the isolation of the people living on the borders of the Colony. "Calvinism carried the Trek. Religion was not restricted to the walls of a Church but was practised in everyday life, determining their worldview and their management of state affairs" (Van der Walt 1938:68 - verbatim).

Although the Pietism and Methodism came to South Africa in 1786 in person of the young preacher Van Lier and also M C Vos, the farmers living in the interior had no contact with them. Isolated in Church and school, also for the duration of the Trek, there are no traces of Pietism and hypocrisy in the Transvaal. The people's faith 
is firmly built on the patriarchs of the Old Testament with whom they identify.

(Schonken 1914:36, 37 - verbatim)

Although scholars differ from each other regarding the influence of Pietism and Methodism and their Dutch counterparts, it is clear from these few references that both these traditions influenced the spirituality of the $19^{\text {th }}$ century Afrikaners.

Liberal Protestantism advocated rationality, discarded orthodox opinions which were not compatible with rationality and a scientific outlook, fostered an optimistic view of man's inherent morality, was inclined towards historism and stressed God's direct indwelling in man rather than his objective existence (Deist 1984:94).

In general, Afrikaners viewed Liberalism as a British trend (Dreyer 1977b:8), but the Liberal theology also came from the Netherlands. In the Zuid Afrikaansche Republiek (ZAR), the ideas of influential liberal settlers from the Netherlands (Dreyer 1977b:9) and others like the liberal minister T F Burgers, who studied in the Netherlands and became president of the ZAR, caused division and tension (Giliomee 2003:187).

The huge influence of the Liberal theology in South Africa is seen in the struggle of the Cape synod between 1862 and 1870 (cf Dreijer 1898). The result was that the Dutch Reformed Church remained territorially split for more than a century (Giliomee 2003:207). The orthodox side developed an evangelical strand in their religion during these troublesome years and the Great Revival swept the western part of the Cape in the early 1860's (Giliomee 2003:208). After the battle against the Liberal Theology was won, the Church retained its confessional character, with a strong overlay of evangelism (Giliomee 2003:209). On this, Strauss (2000:139) comments that the confessional conservative trend and the evangelical (Methodist) or charismatic trend (as we know it today - Dreyer 1998:242) worked side by side and hand in hand to combat Liberalism. The fact that these trends did not develop consecutively, but simultaneously, kept them in balance and prevented both from one-sidedness.

\subsubsection{Calvinism}

Calvinism, as the theology and the ecclesiastical tradition, was upheld by the followers of the reformer John Calvin. They emphasised the sovereignty of God, the total depravity of human nature, divine election and rejection, the supreme authority of the Bible, the necessity of the Church and of sacraments and the necessity of glorifying God in every sphere of life (Deist 1984:23). 
Calvinism is more conservative than most of the other confessions of faith, and consequently conservatism also became part of Afrikaner spirituality. Like everything else that came to Africa, Calvinism underwent certain changes in the hands of the Afrikaners. Giliomee (2003:269) quotes G J Schutte (1987) on this: "More than Catholicism or Lutheranism, Calvinism insisted on remaking this world according to distinct principles derived from or read into the Bible." Akenson (1992:160) says:

We do not find "Calvinism" in the sloppy, generalized sense of the word. And crucially, we do not even find Calvinism in the technical, theological sense. After an intensive study of eighteenth- and nineteenth-century Afrikaner theological development, J Alton Templin [1984:284] concluded "in the absence of trained theologians among the Boers on the frontier and in the republics, a lay piety developed among respected and pious leaders. Consequently, South African theology was not explicit, seldom systematic, seldom orthodox, and not based on educated theological leadership. Most religious leaders knew little more about Calvinism than the name".

Meyer's (1940:27) observation about Afrikaner Calvinism (more than fifty years earlier) stands in direct contrast to this. He argues that the Afrikaner nation is the only nation that came into being as a Calvinistic nation. From the very first moments of the birth of this nation and all through its development, the Afrikaner nation was formed, in every aspect of life, by Calvinistic faith (Meyer 1940:27). In theory, this is true, but the words of Akenson regarding the misuse of Calvinism in the South African context are more correct: "... the concept of Calvinism has been made to carry much more weight than it can bear" (Akenson 1992:56). He says that "Calvinism" has been used by both those who wanted to provide an apologetic perspective of Afrikaner culture, and those who disliked the Afrikaners and used it to label them as "primitive", "fanatic", and "fundamentalists" (Akenson 1992:56).

"A series of publications about Afrikaner culture had already established the fact that the [Calvinistic] belief system that has dominated modern Afrikaner society was a product of the 1870's and thereafter" (Akenson 1992:5). When the Afrikaner world turned upside down after the discovery of gold and diamonds, Calvinism was sucked up like water into a dry sponge by the Afrikaners as the one tool that helped them to face the "new" world. During these years, Paul Kruger, who was a stern Calvinist played a major part (Giliomee 2003:177). 


\subsection{Non-religious influences on Afrikaner spirituality}

\subsubsection{Romanticism}

Romanticism (1760-1830) was a reaction against the Rationalism of the previous century (Oberholster 1965:2) and it soon formed part of the worldview of the Afrikaners who adopted and altered it to suit their circumstances and cherished it as their own. These characteristics did not fade or make way for new ideas, but was taken with the Voortrekkers into the interior of the country where it played a major part in the shaping of the nation until well past the Second Anglo-Boer War (cf Oberholster 1965:10, 11).

Deist (1984:147) defines Romanticism as "a trend in philosophy, literature and art in the late $18^{\text {th }}$ and early $19^{\text {th }}$ centuries whose adherents prized and cultivated the emotional and mystical sides of human life rather than the intellectual, set great store by the beauty of nature, and took a special interest in the distant past and in primitive cultures, which they tended to see as better and purer than their own times and civilization."

Most of the typical characteristics of Romanticism can be found in early South African society. Oberholster depicts the Christian faith as a major characteristic of Romanticism (Oberholster 1965:7). Van Zonneveld remarks that the people living in the $19^{\text {th }}$ century were drenched with faith (Van Zonneveld 1987:20). They believed that the fate of the nation as well of the fate of every individual was held by the greater power of God Almighty (Dreyer 1977a:40). The Afrikaner nation saw the world, everything around them and everything that happened to them, through religiously tinted glasses. The very existence of the nation and the lives of everyone, from the leaders to the farmers, were influenced by their religion. No science, logic or even hard evidence could change the mind of Afrikaners that was set to believe only the Bible. Judgement of all things and people was done by the laws and commandments learned from the Bible (mainly Old Testament).

Afrikaners took the historical focus of Romanticism (Oberholster 1965:6) and centred it on the Bible. They used the Bible to give a firm foundation for their outlook on life. To them, history was synonymous with the history of the Bible and they closely associated with the people and circumstances of the Old Testament. They used Biblical names from the maps at the back of the Bible to name places that looked to them like those on the maps.

Another characteristic of Romanticism is a strong urge for freedom (Oberholster 1965:7). In his heart, the Afrikaner was a farmer, loving nature and animals. By 1851 only 2,000 families were living north of the 26 degree of latitude, stretching over an area of about "71,600 square miles" (Cronje \& 
Venter 1958:15). Some reasons for this were the farming methods (only natural pastures were used) and the low rainfall of the country (Cronje \& Venter 1958:15). By 1870, about 80\% of all Afrikaners were living on farms or rural areas, close to nature (Booyens 1970:33). Historians acknowledge the demand for freedom as a fundamental part of the character of the Afrikaner (cf Garrett-Fisher 1900:35; Eybers 1918:xvii).

Closely linked to the pastoral living of the Afrikaners, was their socalled Wanderlust. Hendrina Joubert comments that they (the Voortrekkers) always had to move in order to get away either from the British or the Native tribes (Rompel-Koopman 1916:12). Van Jaarsveld notes that some historians like Hall, Wilmot and Chase postulate that the Afrikaners were lawless revolutionaries who fled from civilisation (Van Jaarsveld 1958:11). It does seem to be a characteristic of the Afrikaners to become restless whenever living conditions or the government agitates them. Rose (1902:11) comments on the Afrikaners' love of independence:

\begin{abstract}
No less intense than their religious faith is their love of independence. Their history is one long record of trekking away from the domination of Great Britain in accordance with their national and ineradicable craving for complete freedom from control. This is really more than a mere sentiment with them; it amounts to a veritable passion, the strength and intensity of which is simply not understandable by those who have not come into actual contact with these people.
\end{abstract}

The search for independence led Afrikaners to spread through Africa. Leaders of the Thirst Land Trek could not explain the yearning in their hearts to pack their wagons and move further north into Africa (Jooste 1974:17, 18). Du Plessis (1900:258 - verbatim) remarks: "He must trek; nothing in the world can stop him."

A reaction of Romanticism against Rationalism of the Enlightenment was the strong emotional and sentimental emphasis on life (Oberholster 1965:8). In South Africa, this was evident in the emotional spiritual songs that formed part of the day-to-day life of the Afrikaners (cf Van Rooyen 1940:2737).

Van Zonneveld (1987:24) refers to the strong family ties that formed part of the Romantic era. In the Netherlands and in South Africa the gesin (immediate family or household) had its own special meaning. The social unit of the Afrikaner nation was the family (Moodie 1835:165). It was the household that formed the cornerstone of society and everyone had his and her own place and designated job (Van Zonneveld 1987:24). The family Bible 
contained the names and dates of every marriage, birth and death in the family (cf Pretorius 1992:63). Babies were named after grandfathers and grandmothers (Cronje 1945:334), and strangers were always asked about their families over the very first cup of coffee (cf Cronje 1945:334).

The Bible and huisgodsdiens (family worship) were the outstanding factors that acted as glue to make the family unit a strong fortress (Meyer 1940:63). The Biblical norm of the family as an institution ordered by God, was kept and therefore the authority of the father was respected even by married children (Keyter 1940:86). "There alone you will find obedience to parents as strict as among the ancient Sabines, the severa mater, whose sons fetch and carry at her bidding" (Froude 1886:37). The unity of the family as a social and self-sufficient workforce grew to a strong characteristic of the Afrikaner nation living in the Zuid-Afrikaansche Republiek (Meyer 1940:63). "Built firmly on the family tradition of living faith to the letter of the Biblical laws, this resulted in unique households: The father and his married children stayed together on gigantic farms, each with his own house and garden and cattle. "I never saw so much unity, childlike obedience and respect woven together" (Stuart 1854:208 - verbatim).

Although nationalism played a major part in the Romantic era (Oberholster 1965:6), it never really united Afrikaners. Their strong-minded individuality, unwillingness to follow where others led, and pride, always managed to bring division and discord among Afrikaners (Wichmann 1941:2). It was only after the success of the First Anglo Boer War that the flame of nationalism began to spark, but it soon died out again. During and after the Second Anglo Boer War, the disunity became clear again.

Aspects of Romanticism like the emphasis on religion, freedom, and history suited the Afrikaner's needs and they adopted and altered it into a unique South African trend.

\subsubsection{Unique African living conditions}

Poor roads, the lack of modern technology, slow transport and numerous other factors isolated the farmers on their huge farms from frequent contact with people living in the towns and villages (Grobbelaar 1974:158). "The Boer character was formed in the isolation of the veld and amidst the insecurity and turbulence of the expanding frontier" (Patterson 1957:291). The family members learned to depend on one another for support and survival (Wilcocks 1945:298).

This isolation of the Afrikaner helped to build a very conservative character. "The Boer is a born conservative" (Froude 1886:38). Everything that was intended to change or improve their customs was frowned upon as 
either "English" or the "antichrist" (Weilbach \& Du Plessis 1882:24).

Conservatism was not an abstract intellectual outlook on life. It was a practical way of living day-to-day life. Generation after generation used the same farming methods (Wilcocks 1945:294), spoke the same language and observed the same customs, preserving the unique Afrikaner spirituality.

From the first moments of its existence, the Afrikaner nation was under pressure. In the early years, the inter-ethnic pressure came from the other tribes and nations living in South Africa, but from the end of the $18^{\text {th }}$ century it came from the British Empire (Coetzee 1977:155). The discovery of gold and diamonds had devastating consequences. The once poor, unheard of country on the southern point of Africa became a focus point on the world map. Development came overnight. Afrikaners faced strange worldviews and foreign religions. Despite pressure to conform, the Afrikaners stayed true to themselves by clinging to their culture, religion, and language while depending on their physical strength to overcome obstacles (Coetzee 1977:156).

\section{MODERN-DAY AFRIKANER SPIRITUALITY}

During the $19^{\text {th }}$ century, a mixture of influences helped to create Afrikaner spirituality to result in a complex tradition that later transformed into dogma in some circles, dictating Afrikaner spirituality during the $20^{\text {th }}$ century. In the $21^{\text {st }}$ century, many theologians urge believers to cling to tradition, not realising that the tradition is not as purely "Reformed" or "Calvinistic" as they would like or wish it to be.

The inherited strong-minded individualism of Afrikaners makes it impossible to speak of a collective Afrikaner spirituality. This becomes more clear when we look at what is happening inside the churches. On the one hand, the traditional Neo-Calvinism set the stage for the 2006 Synod meeting of the conservative Gereformeerde Kerke (Reformed Churches) while the Charismatic and/or Evangelical influences of American theologians like Rick Warren, George Barna and Leonard Sweet - to name but a few - is escalating daily in the more liberal community churches. Afrikaner spirituality in the $21^{\text {st }}$ century is a complex mixture of traditions carried forward from previous generations and trends from modern theological and philosophical schools.

\subsection{Modernism and Postmodernism}

Inbody (1994:525) sees modernity as "a body of attitudes and ideas. Its key feature was its reconception of knowledge ... through critical reason ...." Modernism dictated society since the Enlightenment. De Kiewiet, however, notes that the Voortrekkers were unaware of the Industrial Revolution. He 
says that in a sense the Great Trek was the eighteenth century fleeing before its more material, more active, and better-organised successor (De Kiewiet 1941:58). Modernism gained momentum in South Africa since the beginning of the $20^{\text {th }}$ century and had its peak during the Apartheid regime.

"Apartheid was a modernist enterprise in the sense that it was a "grand narrative," a grand design, a blueprint for society. It was believed to be based on objective and incontestable (biblical) principles and carried out by an effective bureaucracy. It was a prime example of man manipulating society and human nature in the name of ideology and rationality" (Loubser 1994:162). The "biblical principles" were stated and defended by the Afrikaans speaking churches and it had an enormous effect on Afrikaner spirituality and identity during the $20^{\text {th }}$ century. The dismantling of Apartheid contributes largely to the current crisis regarding the "Reformed identity". The foundation of Afrikaner spirituality was shaken by this sudden and dramatic transformation from Modernism to Postmodernism.

Postmodernism depicts a belief in a discontinuity between the European modern era and the present. Postmodernism observes a selfdistancing of present society, culture or intellectual culture from the modern; it expresses doubts about a consciousness of the limitations of what is referred to by the Eurocentric use of the term "modern" (Cahoone 1995:7).

Osborn notes that although Postmodernism arose since the 1970's, it developed gradually from the start of the $20^{\text {th }}$ century. Osborn (1999:94-96) distinguishes five characteristics of Postmodernism:

- The critical or hermeneutical idea argues the absence of any final or "true" meaning. The reader rather than the text is the final arbiter of meaning and all interpretation is synchronic.

- The moral side centres upon the absence of mandatory convictions. Moral and ethical behavior is seen not as the result of any final reality of force such as God but as the societal needs thrust upon the members of that society.

- The societal influence is radical pluralism and tolerance. Since modern culture is defined by diversity, and since no single view or movement can be more "true" than any other, everyone must respect the beliefs and distinctives of the others.

- The religious concept is radical pluralism and universalism. If all religions are social constructs, and none are inherently superior to any 
other, then all religions are equally valid, and all paths lead one to "God" however that abstract notion is defined.

- The practical aspect of Postmodernism is the triumph of pragmatism, or the old adage, "the end justifies the means."

\subsection{The current situation}

Today, Afrikaners call themselves "Christians". The Christian percentage of the population increased from $74 \%$ of the population in 1996 to nearly $80 \%$ in 2001 according to the last two censuses. But "... those who regard themselves as Christian do not live out their faith in their daily lives ... being 'Christian' is merely a label and not a belief or value system. This is supported by the statistics on crime, violence and other ethical and moral issues obtained from official sources and other research" (Froise 2004:7, 8). This accusation by Froise also finds support in church statistics. The Nederduitse Gereformeerde Kerk which is the biggest Afrikaans speaking church lost more than 270000 members during the past twenty years (Oliver 2006:126).

It seems as if the influence of the Postmodernism is much bigger than people assume. When confronted with the characteristics of the Postmodernism, Afrikaners usually see themselves as onlookers and intentionally uninvolved bystanders or even victims. They observe these trends in daily politics and society, and notice it in the words of academics and works of arts. Although it may be true that Afrikaner spirituality is not greatly influenced by most of the characteristics of Postmodernism, the religious influence of Postmodernism forms a notable part of the Afrikaner society. Osborn (1999:108-111) notes seven areas where the postmodern shift can be seen in the church:

- The market-driven church has taken the place of the Bible-driven church.

- The triumph of secularism has weakened the impact of the church on society.

- There is a sad and incredible increase in Bible illiteracy.

- There is a sharp decline in biblical preaching and teaching.

- Relevance has replaced biblical mandates.

- The power of possessions has turned many Christians into rampant materialists.

- The academy has helped foster the lack of biblical and theological depth in the church. 
Sadly, most of these trends can already be seen in the Afrikaner nation's spirituality.

More than ten years ago, Rossouw (1995:75-93) posed ten challenges to the South African theological society wishing to be of service to the church and community in the postmodernist era. These challenges varied from critical self-reflection, identity formation and religious pluralism to involvement in moral discourse and concern for the marginalized. These are currently major issues in the South African society. One cannot help but wonder if some of the current confusion could be avoided and the chaos turned into opportunities should these challenges be heard and attended to years ago.

Afrikaner spirituality is still a complex mixture of traditions, worldviews, politics and theological trends. All of these need to be taken into consideration when theological guidelines are constructed.

\section{CONCLUSION}

The Afrikaners of $1806-1870$ can be called religious but not outright Christians or Calvinists. They found their theology mainly in the Old Testament. Theological trends, philosophical ideas and the unique living conditions in Africa all influenced the worldview and religion of the nation. This resulted in a unique complex form of Afrikaner spirituality. Towards the end of the $19^{\text {th }}$ century, during a time of extreme external pressure, the Afrikaners retreated to their spirituality as a "shelter" against the world.

A few interesting similarities between the $19^{\text {th }}$ century Afrikaner spirituality and the modern day version of it, can be drawn: When the $19^{\text {th }}$ century Afrikaner took shelter from Calvinism, "living faith" soon died. Modernday Afrikaners are using the label of Christianity but lost the practical side of their faith. $19^{\text {th }}$ century Afrikaners called themselves Christians but lived according to the Old Testament which they knew by heart, while contemporary Christians do not know the contents of the Bible and seldom really study its contents. Living conditions of the Afrikaners changed drastically after the discovery of gold and diamonds in the $19^{\text {th }}$ century. The Afrikaner world turned upside down with the change of government in 1994.

In choosing a new way forward, Afrikaners must remember that a "theology that pretends to be a timeless and closed system of theological knowledge, unaffected by cultural shifts, runs the risk of becoming obsolete, and is itself a reaction to preceding cultural developments. Isolating theology from culture is a coping strategy by theology to deal with the challenges that culture poses to a specific theological interpretation of the world" (Rossouw $1995: 75,76)$. Despite the similarities that were drawn, clinging to the 
traditional spiritualism in answer to the challenges of the current situation may not necessarily be the best or the most practical or desirable option.

Steyn $(2005: 557,558)$ says that Afrikaners tend to wait patiently for the church to tell them what to do in times of uncertainty and trouble. I agree with Theron (2002:301) when he says in his book review on Coenie Burger's "Ons weet aan wie ons behoort: nuut gedink oor ons gereformeerde tradisie" that, like all other historical phenomena, "Reformed" as an independent tradition will cease to exist. It is important to understand both the meaning and the farreaching implications of these words, if the church wants to give meaningful prescriptions to believers on how to react to the current identity crisis.

Theron continues by saying that it is not the tradition, but the evangelical message that was important to our theological forefathers (Theron 2002:302). In this same spirit, only the Bible, and neither Calvinism nor any other temporary theological phenomenon, can serve as ultimate source for the church and believers to make sense of the current problems and opportunities regarding faith and religion. As Christians our focus should be on Christ. Our spirituality and religion must build on Him rather than on traditions (regardless of how fond we may be of them).

The Afrikaans speaking churches should react immediately to the current crisis regarding spiritual identity. Knowledge of the past gives vital information on how the present situation is developing and can act as a guide through dangerous pitfalls. By accepting the fact that the traditional Afrikaner spirituality is a complex mixture, it becomes possible to (like the past generations of Afrikaners did) take from the different influences, worldviews, religious trends and theologies what is true and tested against the Word of God and use it as cornerstones on which Christians can build a fresh

Christian Afrikaner spirituality without defying the foundation.

\section{Works consulted}

Akenson, D H 1992. God's peoples: Covenant and land in South Africa, Israel, and Ulster. New York: Cornell University Press.

Augustijn, C (ed) 1987. Abraham Kuyper. Delft: Meinema.

Booyens, B 1970. Wesenskenmerke van die Afrikaner se identiteit. Handhaaf 1970, 29-34.

Cahoone, L E 1995. The ten modernisms, in Rossouw 1995:1-33.

Calpin, G H 1944. There are no South Africans. London: Nelson.

Coetzee, J H 1977. Die Afrikaner: definisie en konsep. Koers XLII(3), 146-165.

Cronje, G \& Venter, J D 1958. Die patriagale familie: 'n Kultuursosiologiese studie. Pretoria: HAUM.

Cronje, G 1945. Die huisgesin in die Afrikaanse kultuurgemeenskap, in Van den Heever \& Pienaar 1945:309-361.

Deist, F E 1984. A concise dictionary of theological terms. Pretoria: Van Schaik. 
De Kiewiet, C W 1941. A history of South Africa: Social and economic. London: Oxford University Press.

Den Boer, W 1966. Terminologie en waardeoordeel in de geschiedwetenschap. Standpunte 19(4), 23-35.

Dreijer, A 1898. De strijd onzer vaderen tegen het liberalisme. Kaapstad: Jacques Dusseau.

Dreyer, P S 1977a. 'n Tipering van Afrikanerskap, in Nel 1977:37-47.

Dreyer, P S (ed) 1977b. Afrikaner liberalisme. Pretoria: Boekenhout-uitgewers.

Dreyer, P S 1998. Koers(e) van die Afrikaner in die geskiedenis. HTS 54(1\&2), 226244.

Du Plessis, C N J 1900. Uit de geschiedenis van de Zuid-Afrikaansche Republiek en van de Afrikaanders. Amsterdam: De Bussy.

Engelbrecht, B J 1977. Die godsdiens van die Afrikaner, in Nel 1977:48-63.

Eybers, G W 1918. Select constitutional documents illustrating South African history, 1795-1910. London: George Routledge.

Froise, M 2004. Is Christianity in South Africa a label or a spiritual and ethical value system? A study of Christian adherence in the city of Welkom. DTh Dissertation, University of South Africa.

Froude, J A 1886. Oceana or England and her colonies. London: Longmans.

Fuller, R H 1908. South Africa at home. London: George Newnes.

Garrett Fisher, W E 1900. The Transvaal and the Boers. London: Chapman Hall.

Giliomee, H 1975. The development of the Afrikaner's self-concept, in Van der Merwe 1975:1-39.

Giliomee, H 2003. The Afrikaners: Biography of a people. Cape Town: Tafelberg.

Grobbelaar, P W 1974. Die Afrikaner en sy kultuur, Deel 1: Mens en land. Kaapstad: Tafelberg.

Hoge, J 1945. Die Duitsers in die Afrikaanse wordingsgeskiedenis, in Van den Heever \& Pienaar 1945:155-184.

Inbody, T 1994. Intellectual velcro dragged across culture? Theology Today 51, 524538.

Jeppe, C 1906. The kaleidoscopic Transvaal. Cape Town: Juta.

Jooste, J P 1974. Gedenkboek van die Dorslandtrek. Potchefstroom: Herald.

Kennard, D W (ed) 1999. The relationship between epistemology, hermeneutics, biblical theology and contextualization: Understanding truth. Lewiston NY: Edwin Mellen.

Keyter, J de W 1940. Die huwelik en gesin. Bloemfontein: Nasionale Pers.

Landman, C 2005. Leefstyl-Bybel vir vroue: Afrikaans-speaking woman amist a paradigm shift. Studia Historiae Ecclesiastica XXXI (1), 147-162.

Lichtenstein, H 1928. Travels in Southern Africa in the years 1803, 1804, 1805 and 1806, Part 1. Cape Town: Van Riebeeck Society.

Loubser, J A 1994. Postmodernism, post-apartheid theology and New Testament studies, in Mouton \& Lategan 1994:159-177.

MacCrone, I D 1961. The frontier tradition and race attitudes in South Africa. Race Relations Journal 28(3), 19-30.

Moodie, J W D 1835. Ten years in South Africa: Including a particular description of the wild sports of that country. London: Bentley.

Mouton, J \& Lategan, B (eds) 1994. The relevance of theology for the 1990's. Pretoria: HSRC Publishers. 
Nel, P G (ed) 1977. Die kultuurontplooiing van die Afrikaner. Pretoria: HAUM.

Nepgen, C C 1938. Die sosiale gewete van die Afrikaanssprekendes. Stellenbosch: Pro Ecclesia.

Oberholster, J J 1965. Die neerslag van die Romantiek op ons geskiedskrywing: Gustav S Preller. Bloemfontein, Universiteit van die Oranje Vrystaat.

Oliver, E 2005. The impact of Christian education on the Zuid-Afrikaansche Republiek. DTh Dissertation, University of South Africa.

Oliver, E 2006. Sunday School: Past and present. Studia Historiae Ecclesiasticae XXXII(1), 117-134.

Osborn, G R 1999. Christianity challenges postmodernism, in Kennard 1999:93-116.

Patterson, S 1957. The last trek: A study of the Boer people and the Afrikaner nation. London: Routledge.

Pretorius, J C (ed) 1988. Op Trek: Die daaglikse lewe tydens die Groot Trek. Melville: Scripta Africana.

Pretorius, J C 1992. Die geskiedenis van volkskuns in Suid-Afrika. Vlaeberg: Vlaeberg.

Raath, A W G 2004. Covenant, calling and democracy: The foundations of Paul Kruger's political theology. Studia Historiae Ecclesiasticae XXX(2), 134-191.

Rompel-Koopman, L 1916. Wat mevrouw generaal Joubert vertelt. Kaapstad: De Bussy.

Rose, E B 1902. The truth about the Transvaal: A record of facts based upon twelve years residence in the country. London: Rose.

Rossouw, G J (ed) 1995. Life in a postmodern culture. Pretoria: HSRC.

Rossouw, G J 1995. Theology in a postmodern culture: Ten challenges, in Rossouw 1995:75-93.

Saayman, C 2005. Voëlvlug oor die Kerkgeskiedenis. Vox Viva. Gereformeerde Internet Tydskrif 32 (Julie):23/03/06.

Schonken, F T 1914. De oorsprong der Kaapsch-Hollandsche volksoverleveringen. Amsterdam: Swets Zeitlinger.

Schutte, G J 1987. Abraham Kuyper: Vormer van een volksdeel, in Augustijn 1987:933.

Sentrale Volksfeeskomitee 1938. Gedenkboek 1838-1938 Voortrekker-Eeufees. Johannesburg: Sentrale Volksfeeskomitee.

Steyn, G J 2005. Die NG Kerk se identiteitskrisis, Deel 1. Aanloop, terreine van beïnvloeding en reaksie. NGTT 46(3\&4), 550-559.

Stockenström, s a. E Die vrou in die geskiedenis van die Hollands-Afrikaanse volk: 'n Beknopte oorsig van die rol wat die vrou in die geskiedenis van Suid-Afrika gespeel het in die 350 jaar tussen 1568 en 1918. sl.

Strauss, S A 2000. Die dogmatiese lyn in die Nederduitse Gereformeerde kerk, in Tolmie 2000:117-146.

Stuart, J 1854. De Hollandsche Afrikanen en hunne Republieken in Zuid-Afrika. Amsterdam: Tielkemeijer.

Templin, J A 1984. Ideology on a frontier: The theological foundation of Afrikaner nationalism, 1652-1910. Westport: Greenwood.

Theron, F 2002. Book review on Burger, C 2001. Ons weet aan wie ons behoort: nuut gedink oor ons gereformeerde tradisie. NGTT 43(1\&2), 299-302. 
Tolmie, D F (ed) 2000. Kaleidoskoop 2000: Artikels oor teologie: Gedenkuitgawe Fakulteit Teologie UOVS 1980-2000. Acta Theologica 2000. (Supplementum 1.)

Van den Heever, C M \& Pienaar P de V (reds) 1945. Kultuurgeskiedenis van die Afrikaner: Die eerste beskrywing van die Boerevolkslewe in al sy vertakkinge 1945-1950, Deel 1. Kaapstad: Nasionale Pers.

Van der Merwe, H W 1975. Looking at the Afrikaner today. Cape Town: Tafelberg. Van der Merwe, P J 1995. The migrant farmer in the history of the Cape Colony, 1657-1842. Athens: Ohio University Press.

Van der Walt, J J 1938. Calvinisme in ons volksverlede, in Sentrale Volksfeeskomitee 1938:68-72.

Van Jaarsveld, F A 1958. Die Afrikaner se geskiedenisbeeld. Pretoria: UNISA.

Van Rooyen, G H 1940. Kultuurskatte uit die Voortrekkertydperk: 'n Kultuurhistoriese studie, Deel 2. Kaapstad: Nasionale Pers.

Van Zonneveld, P 1987. Panorama van de 19e eeuw: De tijd van Romantiek en Biedermeier. Amsterdam: Bulkboek.

Von Meyer, W J 1843. Reizen in Sud Afrika wahrend der jahre 1840 und 1841. Hamburg.

Weilbach, J D \& Du Plessis, C N J 1882. Geschiedenis van de emigranten-boeren en van den Vrijheidsoorlog. Kaapstad: Saul Solomon.

Wichmann, F A F 1941. Die wordingsgeskiedenis van die Zuid-Afrikaansche Republiek 1838-1860. Kaapstad: Staatsdrukker.

Wilcocks, R W 1945. Die volksaard van die Afrikaner, in Van den Heever \& Pienaar 1945:286-308. 